\title{
Effect of Leaf Litter Treatment on Soil Microbial Biomass
}

\author{
Pramod Sen Oli ${ }^{*}$, Tej Narayan Mandal1, Usha Adhikari² \\ ${ }^{1}$ Department of Botany, Post Graduate Campus, Tribhuvan University, Biratnagar, Nepal \\ ${ }^{2}$ Central Department of Botany, Tribhuvan University, Kathmandu, Nepal \\ Email: *psenoli17@gmail.com, tnmandal@gmail.com
}

How to cite this paper: Sen Oli, P., Mandal, T.N. and Adhikari, U. (2018) Effect of Leaf Litter Treatment on Soil Microbial Biomass. Open Journal of Soil Science, 8, 175-185.

https://doi.org/10.4236/ojss.2018.88014

Received: May 5, 2018

Accepted: August 12, 2018

Published: August 15, 2018

Copyright (c) 2018 by authors and Scientific Research Publishing Inc. This work is licensed under the Creative Commons Attribution International License (CC BY 4.0).

http://creativecommons.org/licenses/by/4.0/

(c) (i) Open Access

\begin{abstract}
Soil microbial biomass is an active fraction of soil organic matter. It shows quicker response than soil organic matter to any change in the soil environment. Being an index of soil fertility, it plays a key role in the decomposition of litters and fast release of available nutrients. Leaf litters of leguminous and non-leguminous species in alone and mixed form were applied as treatments in the soil to observe the changes in the magnitude of soil microbial biomass. Soil microbial biomass $\mathrm{C}$ and $\mathrm{N}$ were determined by chloroform fumigation extraction method. Increment in the concentration of microbial biomass $\mathrm{C}$ and $\mathrm{N}$ was higher in the treatments with leguminous leaf litter (497 - 571 $\left.\mu \mathrm{gCg}^{-1}, 48-55 \mu \mathrm{gNg}^{-1}\right)$ than the non-leguminous one $\left(256-414 \mu \mathrm{gCg}^{-1} ; 22\right.$ $\left.36 \mu \mathrm{gNg}^{-1}\right)$. However, when non-leguminous litters were mixed with leguminous litters then the values increased distinctly $\left(350-465 \mu \mathrm{gCg}^{-1}, 28-48\right.$ $\left.\mu \mathrm{gNg}^{-1}\right)$. On the basis of increment in soil microbial biomass, leaf litters of the species considered potential to improve soil nutrients are-Cassia siamea and Dalbergia sissoo from leguminous trees, Anthocephalus + Cassia and Shorea + Dalbergia from mixed form of non-leguminous and leguminous one and Eichhornia crassipes, an alien aquatic macrophyte. The leaf litters of these species can be used as source of organic matter to improve the crop yield.
\end{abstract}

\section{Keywords}

Leaf Litter of Leguminous Trees, Non-Leguminous Trees, Soil Organic Matter, Soil Microbial Biomass

\section{Introduction}

Management of microbial community in soil through residue placement has a great potential for organic matter and nutrient management in natural and agro-ecosystem. Leaf litter of different tree species have different decomposition 
rate. Generally, leaf litters of leguminous trees have fast decomposition rate than non-leguminous leaf litters because of having low $\mathrm{C}: \mathrm{N}$ ratio [1]. If non-leguminous leaf litter is mixed with leguminous leaf litter, then the decomposition rate may be faster. High nitrogen concentration of leguminous litter makes close C:N ratio which is required to enhance the rate of decomposition. Further, nitrogen immobilization and mineralization are mainly controlled by initial chemical composition of the plant residue [2].

Soil microbial biomass plays a key role in the decomposition of complex organic matter of plant litters. Organic inputs as leaf litters in the soil increase the level of soil microbial biomass [3]. It represents an active fraction of soil organic matter due to its rapid turnover rate and fast release of available nutrients [4]. The size and turnover of microbial biomass affects the quantity of plant available nutrients. An increase in its size indicates the improvement of nutrients in the soil. Thus, it has been used as an index of soil fertility [5]. Further, it is considered as an important early indicator of changes that may occur in the long term and constitutes a source and sink of nutrients [6].

There is an increasing global concern about the decreasing trend of soil organic matter and plant available nutrients due to addition of inorganic fertilizer alone. To improve the yield and achieve sustainable production, use of organic resources is recommended. Several works in this direction have resolved this conclusion [7] and [8]. Further, proper combination of high quality litter (low $\mathrm{C}: \mathrm{N}$ ratio) and low quality litter (high C:N ratio) decomposes at a rate such that timing of nutrient release synchronizes with plant demand [9].

In the present study, an attempt has been made to assess the effect of leguminous, non-leguminous and its mixed form of leaf litter placement on the level of soil microbial biomass. It may help to manipulate the potential litter quality for the improvement of soil nutrients.

\section{Materials and Methods}

\subsection{Profile of the Experimental Area}

The study was conducted at Post Graduate Campus in Biratnagar. Biratnagar is a metropolitan city of Nepal. It lies in Morang district between $26^{\circ} 23^{\prime}$ and $26^{\circ} 30^{\prime} \mathrm{N}$ latitude and $86^{\circ} 14^{\prime}$ and $87^{\circ} 18^{\prime} \mathrm{E}$ longitude. It is situated at an altitude of $72 \mathrm{~m}$ above mean sea level. Study was conducted from the rice cultivating cropland soil of Post Graduate Campus, Biratnagar.

The climate is tropical monsoon type. There are three distinct seasons in a year. A warm and wet rainy season (June to October), a cool and dry winter (November to February) and hot and dry summer (March to May). Mean monthly minimum temperature ranged between $9.17^{\circ} \mathrm{C}$ and $25.96^{\circ} \mathrm{C}$, while maximum temperature ranged between $21.52^{\circ} \mathrm{C}$ and $33.44^{\circ} \mathrm{C}$. The average annual rainfall was $1821.35 \mathrm{~mm}$ out of which $95 \%$ was received in rainy season. Highest relative humidity (86\%) was recorded in rainy season and lowest (60\%) in dry summer season. 
Biratnagar is a part of Gangetic plain. Soil of this region is essentially made up of materials transported and deposited in the recent times by the tributaries of the Ganga. In general, soil is pale yellow to dark greyish brown colour. The textural class of the soil is loam.

\subsection{Litter Sampling}

Leaf litter of leguminous and non-leguminous tree species was collected from Humse-Dumse community forest of Jhapa District. The forest is located at $4 \mathrm{~km}$ north-west to Damak Bazar, covering an area of 627.5 hectare. The vegetation of the forest is dominated by Sal (Shorea robusta Gaertn.). The main associated species are Lagerstroemia parviflora Roxb., Dillenia pentagyna Roxb. and Terminalia alata Heyne ex Roth. Collection of freshly fallen leaf litter of tree species (Table 1) was done randomly from the forest floor. Leaf litter of two weed species e.g. Eichhornia crassipes (Mart.) Solms and Ipomea carnea Jacq. were collected from road side ditches of Biratnagar.

\subsection{Soil Sampling}

Soil was collected from the rice cultivating cropland of Post Graduate Campus, Biratnagar in January 2013 at the fallow period. Soil was collected randomly from three plots. At each plot soil was collected from three pits $(10 \mathrm{~cm} \times 10 \mathrm{~cm}$ $\times 15 \mathrm{~cm}$ depth), mixed together and pooled as one replicate. Three replicates of soil samples were brought to the laboratory. After removing the surface organic materials and fine roots, it was sieved through a $2 \mathrm{~mm}$ mesh screen. Physico-chemical analysis of the soil was done before litter treatment to represent the control. For the purpose of litter treatment, the soil was filled in earthen pots and three pots for each treatment were used.

Table 1. Plant species selected for leaf litter collection.

\begin{tabular}{ccc}
\hline Plant Species & Local name & Family \\
Leguminous Trees & & \\
Dalbergia sissoo Roxb. ex DC. & Sissoo & Leguminosae \\
Cassia siamea Lam. & Tapre & Leguminosae \\
Non-leguminous Trees & & \\
Anthocephalus chinensis (Lam.) A. Rich ex Walp. & Kadam & Rubiaceae \\
Syzygium cumini (L) Skeels & Jamun & Myrtaceae \\
Shorea robusta Gaertn. & Sakhuwa & Dipterocarpaceae \\
Lagerstroemia parviflora Roxb. & Lote Dhayaro & Combretaceae \\
Terminalia alata Heyne ex Roth & Saj & Dilleniaceae \\
Dillenia pentagyna Roxb. & Tantari & Verbenaceae \\
Tectona grandis L.f. & Tick & \\
Non-leguminous Shrub & & \\
Ipomea carnea Jacq. & & Convolvulaceae \\
Aich & &
\end{tabular}




\subsection{Experiment Design}

\section{Treatments}

Leaf litter treatment was applied as follows:

1) Leguminous, non-leguminous, aquatic macrophyte and non-leguminous shrub in alone condition: $50 \mathrm{~g}$ of the leaf litter was used for each species in triplicate.

2) Combination of leguminous and non-leguminous in mixed condition: $25 \mathrm{~g}$ of leguminous and $25 \mathrm{~g}$ of non-leguminous leaf litter was used for each combination in triplicate.

3) Three replicates were used as control.

Leaf litters were kept in earthen pots at the sub-surface layer of the soil and then covered with soil to regulate the decomposition. To enhance the decomposition, water was added for three months maintaining the moisture level. After 3 months, soil of each earthen pot was poured on paper separately and mixed to make uniformity in the soil sample and soil microbial biomass was determined in these samples.

\subsection{Soil Physico-Chemical Analysis}

Physico-chemical properties of the untreated soil were analyzed at the beginning of the experiment. Particle size analysis was done by sieve method. Water holding capacity (WHC) was determined by perforated circular brass box and soil $\mathrm{pH}$ was measured by using a glass electrode (1:5, soil: water) [10]. Soil organic carbon was analyzed by dichromate oxidation in a reflux system and titration with ferrous ammonium sulphate [11]. Total nitrogen was estimated by micro Kjeldhal method [12].

Soil microbial biomass $\mathrm{C}$ and $\mathrm{N}$ were estimated by chloroform fumigation extraction method [13] and [14]. Soil samples (25 g) were saturated with purified liquid $\mathrm{CHCl}_{3}$ for $24 \mathrm{hr}$. After $24 \mathrm{hr}$, the $\mathrm{CHCl}_{3}$ was removed by evacuation and the soil was extracted with $0.5 \mathrm{M} \mathrm{K}_{2} \mathrm{SO}_{4}$ (1:4, soil: extractant) for 30 minutes. This represented the fumigated samples. Another set of un-fumigated soil samples were also extracted with $0.5 \mathrm{M} \mathrm{K}_{2} \mathrm{SO}_{4}$. Biomass $\mathrm{C}$ and $\mathrm{N}$ were estimated from these fumigated and un-fumigated soil extracts.

Soil microbial biomass $\mathrm{C}$ was determined in the soil extracts of fumigated and un-fumigated samples by dichromate oxidation in a reflux system and titration with ferrous ammonium sulphate. Biomass Carbon (MB-C) was then estimated from the equation: $\mathrm{MB}-\mathrm{C}=2.64 \mathrm{EC}$ [13]. Where $\mathrm{EC}$ is the difference between $\mathrm{C}$ estimated from fumigated and un-fumigated soils both expressed as $\mu \mathrm{gCg}^{-1}$ oven dry soil.

Soil microbial biomass N (MB-N) was determined in the same soil extracts of fumigated and un-fumigated samples using Kjeldahl digestion method [14]. The MB-N value obtained for the un-fumigated soil extract was subtracted from the value obtained from that of fumigated soil extract. The difference in value of $\mathrm{N}$ thus estimated was divided by a $\mathrm{K}_{\mathrm{N}}$ value of 0.54 , assuming that $54 \%$ of the bio- 
mass $\mathrm{N}$ was extracted in $\mathrm{K}_{2} \mathrm{SO}_{4}$ by $\mathrm{CHCl}_{3}$ treatment.

\subsection{Data Processing}

MS-Excel and SPSS were used to process and analyze the data.

\section{Results}

Physico-chemical characteristics of cropland soil used in the pot experiment is presented in Table 2. Texture of the soil was loam with 59\% water holding capacity and $6.6 \mathrm{pH}$. Cropland soil was poor in organic carbon $(0.82 \%)$ and total nitrogen content $(0.08 \%)$. After treatment with leaf litter residues, a distinct variation in soil microbial biomass carbon and nitrogen was observed over the control.

\subsection{Changes in Soil Microbial Biomass Carbon (MB-C)}

ANOVA indicated that variation in soil microbial biomass carbon due to treatment with leguminous and non-leguminous leaf litter was significantly different with that of control ( $\mathrm{p} \leq 0.001)$. Increment was always higher in leguminous treatment than non-leguminous (Tables 3-6).

Table 2. Physico-chemical characteristics of the cropland soil used in the pot experiment.

\begin{tabular}{cc}
\hline Soil Properties & Value (Mean \pm SE) \\
\hline Soil texture & \\
Sand (\%) & $47.2 \pm 3.8$ \\
Silt (\%) & $28.0 \pm 2.5$ \\
Clay (\%) & $23.0 \pm 2.0$ \\
Textural class: Loam & $59.0 \pm 5.3$ \\
Water Holding Capacity (\%) & $6.6 \pm 0.7$ \\
pH & $0.82 \pm 0.9$ \\
Organic Carbon (\%) & $0.08 \pm 0.01$ \\
Total Nitrogen (\%) & $1.41 \pm 0.11$ \\
Organic matter (\%) & 10.3 \\
C:N &
\end{tabular}

Table 3. Soil microbial biomass $\mathrm{C}$, N, their percentage of soil organic $\mathrm{C}$, total $\mathrm{N}$ and their ratio in the soil treated with leguminous leaf litter (Mean $\pm \mathrm{SE}$ ).

\begin{tabular}{cccccc}
\hline \multirow{2}{*}{$\begin{array}{c}\text { Treatments } \\
\text { (Leaf Litter })\end{array}$} & \multicolumn{2}{c}{ Microbial Biomass $\left(\mu \mathrm{gg}^{-1}\right)$} & \multicolumn{2}{c}{ Microbial Biomass as \% of } & MBC:MBN \\
\cline { 2 - 5 } & Carbon & Nitrogen & Organic C & Total N & \\
\hline Control & $182 \pm 12$ & $14.5 \pm 1.7$ & 2.22 & 1.81 & 12.5 \\
Dalbergia sissoo & $497 \pm 46$ & $48.0 \pm 5.2$ & 6.06 & 6.00 & 10.3 \\
Cassia siamea & $571 \pm 48$ & $55.0 \pm 5.7$ & 6.96 & 6.87 & 10.4 \\
\hline
\end{tabular}


Table 4. Soil microbial biomass $\mathrm{C}, \mathrm{N}$, their percentage of soil organic $\mathrm{C}$, total $\mathrm{N}$ and their ratio in the soil treated with non-leguminous leaf litter (Mean $\pm \mathrm{SE}$ ).

\begin{tabular}{cccccc}
\hline \multirow{2}{*}{$\begin{array}{c}\text { Treatments } \\
\text { (Leaf Litter) }\end{array}$} & \multicolumn{2}{c}{ Microbial Biomass $\left(\mu \mathrm{gg}^{-1}\right)$} & \multicolumn{2}{c}{ Microbial Biomass as \% of } & \multirow{2}{*}{ MBC:MBN } \\
\cline { 2 - 5 } & Carbon & Nitrogen & Organic C & Total N & \\
\hline Anthocephalus chinensis & $414 \pm 28$ & $34.0 \pm 3.1$ & 5.05 & 4.25 & 12.2 \\
Dillenia pentagyna & $402 \pm 32$ & $35.0 \pm 2.8$ & 4.90 & 4.37 & 11.5 \\
Lagerstroemia parviflora & $380 \pm 22$ & $36.0 \pm 2.7$ & 4.63 & 4.50 & 10.5 \\
Shorea robusta & $256 \pm 28$ & $22.0 \pm 2.5$ & 3.12 & 2.75 & 11.6 \\
Syzygium cumini & $346 \pm 35$ & $31.0 \pm 2.8$ & 4.20 & 3.87 & 11.1 \\
Tectona grandis & $389 \pm 27$ & $32.0 \pm 2.5$ & 4.74 & 4.00 & 12.2 \\
Terminalia alata & $288 \pm 25$ & $30.0 \pm 3.5$ & 3.51 & 3.75 & 9.6 \\
\hline
\end{tabular}

Table 5. Soil microbial biomass $\mathrm{C}, \mathrm{N}$, their percentage of soil organic $\mathrm{C}$, total $\mathrm{N}$, and their ratio in the soil treated with mixed leguminous and non-leguminous leaf litter (Mean \pm $\mathrm{SE})$.

\begin{tabular}{cccccc}
\hline \multirow{2}{*}{$\begin{array}{c}\text { Treatments } \\
\text { (Leaf Litter) }\end{array}$} & \multicolumn{2}{c}{ Microbial Biomass $\left(\mu \mathrm{gg}^{-1}\right)$} & \multicolumn{2}{c}{ Microbial Biomass as \% of } & \\
\cline { 2 - 5 } & Carbon & Nitrogen & Organic C & Total N & \\
\hline Anthocephalus + Cassia & $465 \pm 56$ & $48 \pm 4.1$ & 5.67 & 6.00 & 9.7 \\
Dillenia + Cassia & $389 \pm 36$ & $35 \pm 3.2$ & 4.74 & 4.37 & 11.1 \\
Lagerstroemia + Cassia & $397 \pm 37$ & $43 \pm 3.7$ & 4.84 & 5.37 & 9.2 \\
Shorea + Cassia & $381 \pm 36$ & $32 \pm 3.5$ & 4.64 & 4.00 & 12.0 \\
Shorea + Dalbergia & $460 \pm 48$ & $45 \pm 3.8$ & 5.61 & 5.62 & 10.2 \\
Syzygium + Cassia & $371 \pm 33$ & $32 \pm 3.7$ & 4.52 & 4.00 & 11.6 \\
Tectona + Cassia & $350 \pm 34$ & $28 \pm 3.0$ & 4.26 & 3.50 & 12.5 \\
Tectona + Dalbergia & $388 \pm 40$ & $37 \pm 4.0$ & 4.73 & 4.62 & 10.5 \\
Terminalia + Cassia & $358 \pm 38$ & $30 \pm 2.7$ & 4.36 & 3.75 & 12.0 \\
\hline
\end{tabular}

Table 6. Soil microbial biomass $\mathrm{C}, \mathrm{N}$, their percentage of soil organic $\mathrm{C}$, total $\mathrm{N}$ and their ratio in the soil treated with Eichhornia and Ipomea (Mean \pm SE).

\begin{tabular}{cccccc}
\hline \multirow{2}{*}{$\begin{array}{c}\text { Treatments } \\
\text { (Leaf Litter) }\end{array}$} & \multicolumn{2}{l}{ Microbial Biomass $\left(\mu \mathrm{gg}^{-1}\right)$} & \multicolumn{2}{l}{ Microbial Biomass as \% of } & \multirow{2}{*}{ MBC:MBN } \\
\cline { 2 - 5 } & Carbon & Nitrogen & Organic C & Total N & \\
\hline Eichhornia crassipes & $380 \pm 34$ & $33 \pm 2.8$ & 4.63 & 4.12 & 11.5 \\
Ipomea carnea & $340 \pm 36$ & $27 \pm 3.1$ & 4.14 & 3.37 & 12.6 \\
\hline
\end{tabular}

Within leguminous treatment, MB-C increased by $213 \%$ when amended with Cassia and by $173 \%$ with Dalbergia over the control. Similarly, increment in MB-C was also observed when the soil was treated with non-leguminous leaf litter, but it was always lower than leguminous litter. Within non-leguminous tree leaf litter the MB-C value ranged between $256 \mu \mathrm{gg}^{-1}$ and $414 \mu \mathrm{gg}^{-1}$, the minimum in Shorea and maximum in Anthocephalus. It showed $40 \%$ to $127 \%$ increment 
over the control.

In the case of non-leguminous + leguminous mixed treatment, the increment in $\mathrm{MB}-\mathrm{C}$ was even greater than non-leguminous litter alone which ranged from $350 \mu \mathrm{gg}^{-1}$ to $465 \mu \mathrm{gg}^{-1}$, the minimum in Tectona + Cassia and maximum in Anthoceplatus + Cassia.

Treatment with Eichhornia, a problematic aquatic macrophyte in pond ecosystem showed increment in MB-C content by $108 \%$ while Ipomea, a rapidly growing non-legume shrub showed $86 \%$ increment in $\mathrm{MB}-\mathrm{C}$ than control.

\subsection{Changes in Soil Microbial Biomass Nitrogen (MB-N)}

ANOVA suggested that variation in soil microbial biomass nitrogen due to treatment with leguminous and non-leguminous leaf litter was significantly different with that of control ( $\mathrm{p} \leq 0.001$ ). Leguminous litter amendment showed always higher value than non-leguminous leaf litter (Tables 3-6).

Under leguminous litter amendment, MB-N increased by $279 \%$ with Cassia and by $231 \%$ with Dalbergia over the control. It showed that MB-N increased even by greater percentage than MB-C. Within the non-leguminous treatment also the increment was observed but it was always lower than leguminous litter. The value ranged between $22 \mu \mathrm{gg}^{-1}$ and $36 \mu \mathrm{gg}^{-1}$, the minimum in Shorea and maximum in Lagerstroemia. It showed the increment from 51\% to $148 \%$ over the control.

As it happened in the case of MB-C, the mixed treatment of non-leguminous+ leguminous litter showed greater increment in MB-N over the treatment only with non-leguminous litter. The value ranged between $28 \mu \mathrm{gg}^{-1}$ and $48 \mu \mathrm{gg}^{-1}$. It increased from $93 \%$ to $231 \%$ over the control. It showed that in mixed treatment, the higher value $\left(48 \mu \mathrm{gg}^{-1}\right)$ reached to the level obtained in the treatment with Dalbergia (leguminous) alone.

In the case of MB-N also, Eichhornia and Ipomea showed distinct increment $(86 \%-127 \%)$ over the control.

\subsection{Microbial Biomass as Percent of Organic C and Total N}

MB-C as percent of soil organic carbon and MB-N as percent of total nitrogen showed more than three times increment over the control when it was amended only with leguminous litter (Tables 3-6). Further, even in the case of nonleguminous litter these values showed distinct increment (41\% - 148\%) over the control. Including all treatments, $\mathrm{MB}-\mathrm{N}$ as percent of total $\mathrm{N}$ (increased $52 \%$ $280 \%$ ) was always higher than MB-C as percent of soil organic C (increased $41 \%$ $214 \%)$.

MB-C: MB-N ratio ranged from 9.2 to 12.5 (Tables 3-6). In leguminous treatment MB-C: MB-N ratio was lower (10.3 - 10.4) than the control (12.5). In non-leguminous litter treatment the value ranged between 9.6 to 12.2. Narrow MB-C: MB-N ratio was seen in Terminalia alata (9.6) and wide MB-C: MB-N ratio was observed in Tectona grandis and Anthocephalus chinensis (12.2). 
In mixed combination of non-leguminous + leguminous litter, MB-C: MB-N ratio ranged from 9.2 to 12.5, the lower in Lagerstroemia + Cassia and higher in Tectona + Cassia.

The treatment with Anthocephalus alone showed wide C:N ratio (12:2) but became narrow (9.7) when it is mixed with the legume Cassia. Similarly, Lagerstroemia alone showed C:N ratio as 10.5, but it is lowered to 9.2 when it is mixed with Cassia (legume).

\section{Discussion}

Soil microbial biomass is potentially very important to increase the level of soil fertility. It responds quickly to changes occurring with different types of leaf litter. The decomposition of plant litter plays a crucial role in the nutrient budget of ecosystem. Different plant species affect the soil microbial biomass in different way depending upon their litter quality. In the present study, the variation in the concentration of soil microbial biomass was significant due to litter treatment over the control.

The soil treated with the leaf litter of Cassia siamea showed significant effect and increased the maximum level of soil microbial biomass $\mathrm{C}$ and $\mathrm{N}$. Being a legume plant, it has close C:N ratio in its leaf litter which helps in rapid decomposition of litter [1]. Fast decomposing litter releases the nutrients rapidly which helps the microbial growth.

Under the treatment of non-leguminous leaf litter, Anthocephalus, Dillenia, Tectona and Lagerstroemia supported to develop the level of MB-C and MB-N in a better way than others. However, non-leguminous litters showed lower value for soil microbial biomass in all cases in comparison to leguminous litter treatment. But, when it is mixed with leguminous litter the level of microbial biomass increased distinctly. The C:N ratio of leguminous plant litter is generally low. The low C:N ratio helps in fast decomposition [7]. The $\mathrm{N}$ is immobilized when the C:N ratio is greater than critical ratio and it is mineralized when this ratio becomes narrow. Combination of legume litter with non-legume litter lowered the $\mathrm{C}: \mathrm{N}$ ratio due to high nitrogen concentration.

Under the treatment with mixed form of non-leguminous and leguminous leaf litter, the combination of Anthocephalus + Cassia showed maximum level of MB-C and MB-N than other combinations. The treatment with Eichhornia leaf litter also showed comparable level of microbial biomass with Lagerstroemia. Eichhornia is an aquatic weed and cause eutrophication in water bodies. This weed can be used to manage the soil fertility as it enhances the microbial growth in soil and decomposed completely within 90 days [15].

Microbial biomass responds more rapidly to any change in soil environment than soil organic matter because of its high turnover rate. It constitutes a significant part of the potentially mineralizable $\mathrm{N}$ and serves both as source and sink of nitrogen. Consequently, the microbial biomass nitrogen has significant impact on nitrogen availability and overall soil nitrogen cycling [16]. 
Microbial biomass carbon and nitrogen increased by three times over the control due to addition of legume litter and even $1.4-2.2$ times higher in non-leguminous leaf litter. Growth of microbial biomass on leaf litter treatment enhances the turnover rate of the soil organic matter through concurrent immobilization [17]. The soil microbial biomass $\mathrm{C}$ and $\mathrm{N}$ increased over the control in fallow based rice-wheat system by applying the residues of different types of green manure legumes [18].

Among the non-legume tree species, treatment with leaf litter of Shorea showed comparatively low microbial biomass. This may be due to low nitrogen concentration in leaf litter. Due to higher nitrogen concentration in Cassia $(1.5 \% \mathrm{~N})$, it decomposes at fast rate while Shorea having low nitrogen concentration in leaf litter $(0.82 \% \mathrm{~N})$ decomposes slowly. Consequently, it releases least amount of nitrogen [19]. This may be the reason that Cassia showed maximum value while Shorea showed the minimum value of microbial biomass. Nevertheless, combination of non-leguminous leaf litters with the leguminous leaf litter e.g. Dalbergia and Cassia, have double increment in their microbial biomass. This may be due to the presence of leguminous species where $\mathrm{N}$-mineralization is faster.

As indicated by the status of soil microbial biomass, the leaf litter of Cassia siamea can enrich the nutrient level in soil within a short period. On the other hand, among non-leguminous tree species litter of Anthocephalus chinensis can be considered as good for nutrient management. Similarly, Eichhornia crassipes can also be exploited for nutrient management as it is a problematic aquatic macrophyte, propagating at fast rate and causing eutrophication in the water bodies. Further, in the mixed form of non-leguminous and leguminous litter, $A n$ thocephalus + Cassia could be the best combination. These are the potential plant species to improve the nutrients level in soil. The leaf litter of these species can be exploited to make compost and even in combination with inorganic fertilizer to achieve sustainable production.

\section{Conclusions}

On the basis of increment in the concentration of soil microbial biomass, an index of soil fertility, the leaf litter of following plant species considered potential to improve the nutrients level in soil.

1) Cassia siamea and Dalbergia sissoo from leguminous trees.

2) Anthocephalus + Cassia and Shorea + Dalbergia from mixed form of non-leguminous and leguminous trees.

3) Eichhornia crassipes, an alien aquatic macrophyte.

Leaf litters of these species can be applied to amend the soil and even to make compost with them. Furthermore, to reduce the negative consequence of inorganic fertilizer the above potential litters can be used as source of organic matter to integrate with inorganic fertilizer to improve the yield and achieve sustainable production. 


\section{Acknowledgements}

We are grateful to the Campus Chief and the Head, Department of Botany, Post Graduate Campus, Tribhuvan University, Biratnagar, Nepal for providing laboratory and library facilities.

\section{Conflicts of Interest}

The authors declare no conflicts of interest regarding the publication of this paper.

\section{References}

[1] Upadhyay, V.P. and Singh, J.S. (1989) Patterns of Nutrient Immobilization and Release in Decomposing Forest Litter in Central Himalaya, India. Journal of Ecology, 77, 127-146. https://doi.org/10.2307/2260921

[2] Manzoni, S., Jackson, R.B., Trofymow, J.A. and Porporato, A. (2008) The Global Stoichinometry of Litter Nitrogen Mineralization. Science, 321, 684-686. https://doi.org/10.1126/science.1159792

[3] Li, W., Pan, K.W., Wang, J.C., Wang, Y.J. and Hang, L.Z. (2014) Effects of Litter Type on Soil Microbial Parameter Sand Dissolved Organic Carbon in Laboratory Microcosm Experiment. Plant Soil Environment, 60, 170-176. https://doi.org/10.17221/39/2014-PSE

[4] Walley, F.L., van Kessel, C. and Pennock, D.J. (1996) Landscape-Scale Variability of N-Mineralization in Forest Soils. Soil Biology and Biochemistry, 28, 383-391. https://doi.org/10.1016/0038-0717(95)00153-0

[5] Kara, O. and Bolat, L. (2007) The Effect of Different Land Uses on Soil Microbial Biomass Carbon and Nitrogen in Bartin Province. Soil Science and Ecology, 32, 281-288.

[6] Moussa, A.S., Vanrensburg, L., Kellneri, K. and Bationo, A. (2010) Soil Microbial Biomass in Semi-Arid Communal Sandy Rangelands in the Western Bophirima District, South Africa. Applied Ecology and Environmental Research, 5, 43-56. https://doi.org/10.15666/aeer/0501_043056

[7] Singh, H. and Singh, K.P. (1993) Effect of Residue Placement and Chemical Fertilizer on Soil Microbial Biomass under Tropical Dryland Cultivation. Biology and Fertility of Soils, 16, 275-281. https://doi.org/10.1007/BF00369304

[8] Ghoshal, N. and Singh, K.P. (1995) Effects of Farmyard Manure and Inorganic Fertilizer on the Dynamics of Soil Microbial Biomass in a Tropical Dryland Agroecosystem. Biology and Fertility of Soils, 19, 231-238.

[9] Swift, M.J. (1987) Tropical Soil Biology and Fertility. Interregional Research Planning Work Shop. Biology International Special Issue. 13 International Union of Biological Sciences.

[10] Piper, C.S. (1996) Soil and Plant Analysis. Hans Publisher, Bombay.

[11] Kalembasa, S.J. and Jankinson, D.S. (1979) A Comparative Study of Titremetric and Gravimetric Methods for the Determination of Organic Carbon in Soil. Journal of Science, Food and Agriculture, 24, 1019-1085.

[12] Jackson, M.L. (1958) Soil Chemical Analysis. Printice Hall, Englewood Cliffs, New Jersey.

[13] Vance, E.D., Brookes, P.C. and Jenkison, D.S. (1987) An Extraction Method for 
Measuring Soil Microbial Biomass Carbon. Soil Biology and Biochemistry, 19, 703-707. https://doi.org/10.1016/0038-0717(87)90052-6

[14] Brookes, P.C., Landman, A., Pruden, G. and Jenkison, D.S. (1985) Chloroform Fumigation and the Release of Soil Nitrogen: A Rapid Direct Extraction Method to Measure Microbial Biomass Nitrogen in Soil. Soil Biology and Biochemistry, 17, 837-842. https://doi.org/10.1016/0038-0717(85)90144-0

[15] Maya, A. (2011) Decomposition and Nitrogen Release in Mixed Species (Leguminous and Non-Leguminous) Leaf Litter. Master's Thesis, Tribhuvan University, Kathmandu.

[16] Powlson, D.S., Brookes, P.C. and Christensen, B.T. (1987) Measurement of Microbial Biomass Provides an Early Indication of Changes in Total Soil Matter Due to Straw Incorporation. Soil and Biochemistry, 19, 159-164.

https://doi.org/10.1016/0038-0717(87)90076-9

[17] Hassink, J., Lebbink, J. and van Veen, J.A. (1991) Microbial Biomass and Activity of a Reclaimed-Polder Soil under a Conventional or Reduced Input Farming System. Soil Biology and Biochemistry, 23, 507-513.

https://doi.org/10.1016/0038-0717(91)90107-U

[18] Shah, Z., Rashid Ahmad, S. and Hidyad, Ur.R. (2010) Soil Microbial Biomass and Activities as Influenced by Green Legumes and N-Fertilizer in Rice Wheat System. Pakistan Journal of Botany, 42, 2589-2598

[19] Mandal, T.N. (1999) Ecological Analysis of Recovery of Landslide Damaged Sal Forest Ecosystem in Nepal Himalaya. Ph.D. Thesis, Benaras Hindu University, Varanasi, India. 